\title{
Kajika Frogs (Buergeria buergeri) as Premium Pets During the Japanese Modern Monarchical Period
}

\author{
Hideto Hoshina ${ }^{1 *}$ \\ ${ }^{1}$ Faculty of Education, University of Fukui, Fukui City, Japan. \\ *hhoshina@f-edu.u-fukui.ac.jp
}

\begin{abstract}
This study reviews articles about the prices of Kajika frogs (Buergeria buergeri) in eight Japanese newspapers published between 1884 and 1938. Frog prices have been converted to present-day United States dollars (US\$). The frogs had a wide range of prices. Premium individuals, in particular, were often sold for US\$1,000-2,000. In this paper, I discuss the reasons why exceptional individuals were traded at a high price in the market, although Kajika frogs were a common native species. Other topics, such as the presentation of frogs as gifts to royal families, are also discussed.
\end{abstract}

Received January 7, 2020

OPENOAACCESS

Accepted April 17, 2020

Published September 18, 2020

DOI 10.14237/ebl.11.1.2020.1672

Keywords Japanese singing frogs, Newspaper article, Pet shop, Price, Rearing containers

Copyright $@ 2020$ by the author(s) licensee Society of Ethnobiology. This is an open-access article distributed under the terms of the Creative Commons Attribution-NonCommercial 4.0 International Public License (https://creativecommons.org/licenses/by-nc/4.0), which permits non-commercial use, distribution, and reproduction in any medium, provided the original author and source are credited.

\section{Introduction}

In Japan, there are 48 known frog species (Amphibia: Anura), including invasive species (Matsui and Maeda 2018). Most frogs inhabit ponds, wetlands, and rice paddies. However, a small number of frog species are found in streams. These include the Kajika frog (Buergeria buerger) (Figure 1), which lives in mountain streams, an uncommon habitat for Japanese frogs. Male and female B. buergeri are about 4 and 5-7 cm long, respectively. B. buergeri are well known for their cry (fi fi fi fi fi), which can be heard mainly in the summer and sounds like a song. Their songs can be heard on the website of the Museum of Nature and Human Activities (Hyogo 1997). The Japanese name of the frog is kajika-gaeru, two words that mean "deer in a river" and "frog", respectively, because the frogs' cry is thought to resemble that of a deer. This frog's nickname is "songstress in a clean stream," although only males can sing.

During the Japanese modern monarchical period (1868-1945), almost all frog fanciers reared B. buergeri exclusively in order to listen to their songs (Hoshina 2018c). In previous studies, I examined prices for pet insects, such as Japanese fireflies and crickets, as they appeared in newspaper articles from the modern monarchical period (Hoshina 2017b, 2018a). Currently, people in Japan cannot buy fireflies and singing Orthoptera-except for Meloimorpha japonica (de Haan 1844) - at normal pet shops and summer festivals. Moreover, present-day Japanese newspapers seldom report the prices of pet insects. In contrast, in the modern monarchical period, fireflies and various singing Orthoptera were usually sold at summer festivals (Hoshina 2017b, 2018a), and newspapers often mentioned the prices of these coveted pets. In addition, those newspaper articles included $B$. buergeri prices (Hoshina 2018c). Therefore, I examined the prices of B. buergeri that were kept as pets during the modern monarchical period and have recorded some cultural insights relevant to this frog. The aim of the present study is to show how the value of B. buergeri as a pet animal in Japanese culture changed from the modern monarchical period to the present.

\section{Methods}

In Japanese history, the period between 1868 and 1945 (following the Edo Period) is known as the modern monarchical period. During this period, many newspaper publishing companies were established, and newspapers became popular among ordinary Japanese people. In this study, I look at the prices of $B$. buergeri, which were kept as pets, as they appeared in newspaper articles from the modern monarchical period. 


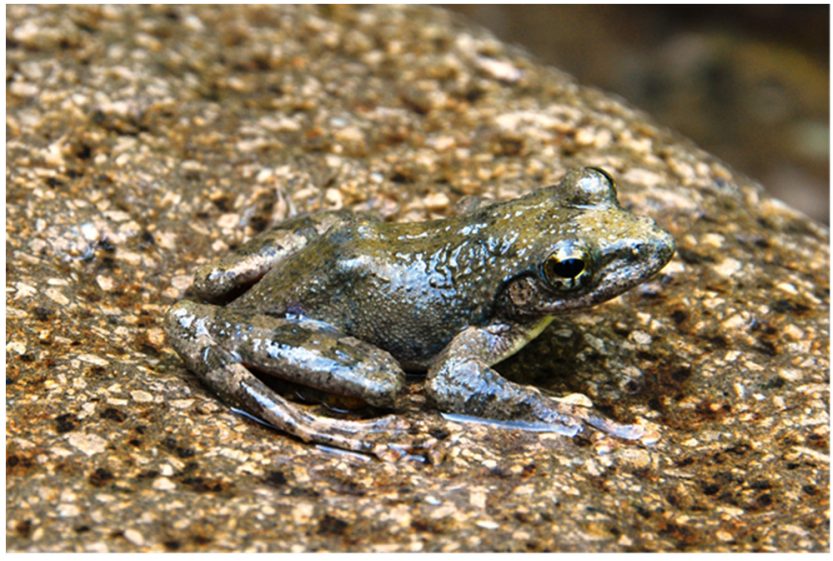

Figure 1 Buergeria buergeri. Photo credit: Kazunori Kawauchi, May 2009.

I mainly conducted research in two newspapers: Yomiuri Shimbun (still in circulation) and Tokyo Asabi Shimbun (now called The Asabi Shimbun) from Japan's modern monarchical period. The Japanese word shinbun means newspaper. In addition, I referred to the Tokyo Yokohama Mainichi Sbinbun, Mainichi Sbinbun, Yorozu Chôbô, Miyako Sbinbun (the present-day Tokyo Shinbun), Un-yu Nippô, and Chûô Shinbun. Except for the Miyako Shinbun, the other newspapers are defunct.

Many newspaper articles contained information on the prices of $B$. buergeri, which were kept as pets, in Tokyo's market, methods for rearing them, and other matters. The main currency types used during Japan's modern monarchical period were yen and sen. One yen was equivalent to $100 \mathrm{sen}$. Eventually, the sen was taken out of circulation, and the only official Japanese currency at present is the yen. Prices varied depending on the period; therefore it is very difficult to have a real sense of the original prices when indicated in sen.

Consequently, I converted modern monarchical prices into present-day United States dollars, an international standard currency. The price of a Tokyo Asahi Shimbun copy in the modern monarchical period ranged from 1-4 sen. In contrast, the average price of a newspaper copy in contemporary Japan ranges from 100-160 yen. The current yen/US dollar exchange rate (December 2019) is about 110 yen per dollar. Therefore, I very roughly estimated that the Tokyo Asabi Shimbun cost US $\$ 1$ per copy. For example, the Tokyo Asabi Sbimbun (1 sen per copy at the time) reported in 1890 that the price of a B. buergeri was 11.5 yen (100-150 sen). Based on this information, I very roughly estimated the price of the frog to be US\$100-150 in 1890.
In Table 1, the nine newspapers Yomiuri Shimbun, Tokyo Asabi Shimbun, Tokyo Yokohama Mainichi Sbinbun, Mainichi Sbimbun, Yorozu Chôbô, Miyako Sbinbun, Un-yu Niphô, and Chûô Sbinbun have been abbreviated as YM, TA, TYM, MA, YR, MI, UN, and CH, respectively. For instance, when I cite a newspaper article from December 8, 1941 in Yomiuri Shimbun, I describe the authentic article as YM. 12. 8. in the table. In the main text, I cite the newspaper article as (Yomiuri Shimbun 1941), and the date, title, and page number of each article is noted in the references. All articles used in this study were examined by reading reprinted editions or microfilms, not the original papers. Page numbers of some articles are unclear.

\section{Results and Discussion}

B. buergeri Sold at a Wide Range of Prices

I found many articles on the prices of B. buergeri sold in Tokyo's market in the eight newspapers that were published between 1884 and 1938 (Table 1). Table 1 shows that the prices of $B$. buergeri ranged from cheap to very expensive. All commercial B. buergeri were living frogs. A prime individual was often sold for US $\$ 1,000-2,000$. For contrast, in 1886 , the daily pay of a carpenter was about 0.4 yen (US\$40) (Morinaga 2008). It follows that commoners could not buy such expensive frogs.

In contemporary Japan, these frogs cost about US\$10-20 in pet shops that specialize in reptiles and amphibians. Now, B. buergeri are commonly found in mountain streams in suburban areas, and in the countryside, where people can hear them sing; the Japanese Ministry of the Environment has not classified this species as endangered. During the modern monarchical period, this frog must have been more common than it is now. For example, B. buergeri were even found in some numbers at the Tama River in Tokyo in those days (Tokyo Yokohama Mainichi Sbinbun 1885; Yomiuri Sbimbun 1927b), although now the frog has been designated a prefectural endangered species (Bureau of Environment, Tokyo Metropolitan Government 2013). So, why was this frog often very expensive during late monarchical times despite being relatively common?

Frogs collected from particular localities were treasured among fanciers in Tokyo. In those days, the frogs collected from Kamogawa River, Kyoto were the most valuable, followed by those collected from Shizuoka and Yamanashi (Yomiuri Sbimbun 1902, 1903b). In contrast, the frogs collected from Saitama and Chiba were considered to be inferior singers 
Table 1 The annual prices of $B$. buergeri.

\begin{tabular}{|c|c|c|c|}
\hline Year & Frog price (yen) & Relative value in USD & Authority ${ }^{1,2}$ \\
\hline 1884 & $0.24-10$ & $24-1000$ & YM. 6. 14. \\
\hline 1885 & $0.15-3$ & $15-300$ & TYM. 6. 19. \\
\hline 1886 & $0.1-20$ & $10-2000$ & MA. 7. 2. \\
\hline 1887 & $0.13-0.5$ & $13-50$ & YM. 7. 28. \\
\hline 1890 & $1-1.5$ & $100-150$ & TA. 6. 26. \\
\hline 1892 & $0.3-0.5$ & $20-33$ & YM. 4. 24. \\
\hline 1892 & $0.15-5$ & $10-333$ & YM. 8. 14. \\
\hline 1895 & $0.5-1$ & $33-67$ & YR. 6. 20. \\
\hline 1897 & $0.2-0.5$ & $20-50$ & TA. 6. 22. \\
\hline 1900 & $0.25-1$ & $17-67$ & YR. 6. 11. \\
\hline 1902 & $0.05-0.28$ & $3-19$ & TA. 6.8. \\
\hline 1902 & $0.2-1$ & $13-67$ & YM. 6. 8. \\
\hline 1903 & $0.25-10$ & $17-667$ & TA. 5. 31. \\
\hline 1903 & $0.1-30$ & $7-2000$ & YM. 6. 27. \\
\hline 1904 & 0.15 & 10 & YM. 7. 11. \\
\hline 1905 & $0.2-30$ & $13-2000$ & YM. 6. 23. \\
\hline 1907 & $0.15-0.3$ & $8-15$ & MI. 5. 28. \\
\hline 1909 & 0.5 & 25 & MI. 8. 26. \\
\hline 1910 & $0.03-0.25$ & $2-13$ & TA. 7.6. \\
\hline 1912 & $0.05-0.1$ & $3-5$ & TA. 4.8. \\
\hline 1917 & $0.5-8$ & $25-400$ & UN. 6. 19. \\
\hline 1919 & $0.1-7$ & $5-350$ & CH. 6. 27. \\
\hline 1920 & $0.4-5$ & $13-167$ & YM. 6. 5. \\
\hline 1921 & $0.4-5$ & $10-125$ & YM. 5. 7. \\
\hline 1922 & $0.4-5$ & $10-125$ & YM. 6. 3. \\
\hline 1924 & 0.5 & 17 & YM. 7. 11. \\
\hline 1926 & $0.5-15$ & $17-500$ & TA. 7.1. \\
\hline 1938 & 0.15 & 4 & YM. 6. 22. \\
\hline
\end{tabular}

${ }^{1} \mathrm{YM}, \mathrm{TYM}, \mathrm{MA}, \mathrm{TA}, \mathrm{YR}, \mathrm{MI}, \mathrm{UN}$, and $\mathrm{CH}$ are abbreviations of newspapers. See text in methods.

${ }^{2}$ The two numbers of newspaper articles in authority are month and day. The years published have been omitted. See year in the first column.

(Miyako Shinbun 1907; Tokyo Asabi Shimbun 1910; Yomiuri Shimbun 1903b). In short, frogs collected in western Japan were more popular among fanciers than those collected in eastern Japan (Figure 2). These frog evaluation differences were directly reflected in the prices. Rich fanciers looked frantically for frogs from Kyoto in the market, and these sold at much higher prices (Yomiuri Sbimbun 1903a). Kyoto frogs were particularly highly esteemed by fanciers because these frogs were the subject matter of poems by great poets at Kyoto in the Heian Period (794-1192) and considered the best singers of all the B. buergeri (Usui 1989). Of course, there is no zoological basis for these evaluations. Rather, these high evaluations of Kyoto frogs reflected Tokyo citizens' longing for the ancient capital of Kyoto.

Old and fat frogs were valued and traded at high prices in the market (Tokyo Asabi Shimbun 1921a; Yomiuri Shimbun 1903b), as large frogs could sing better than small ones. Individuals kept in captivity for a long time had a higher value than those recently collected from rivers. When wild frogs were captured from fields and put in rearing containers, they did not sing immediately. However, frogs that had adapted to living in rearing containers over the course of several years sang very well. In 1903, an old individual worth 


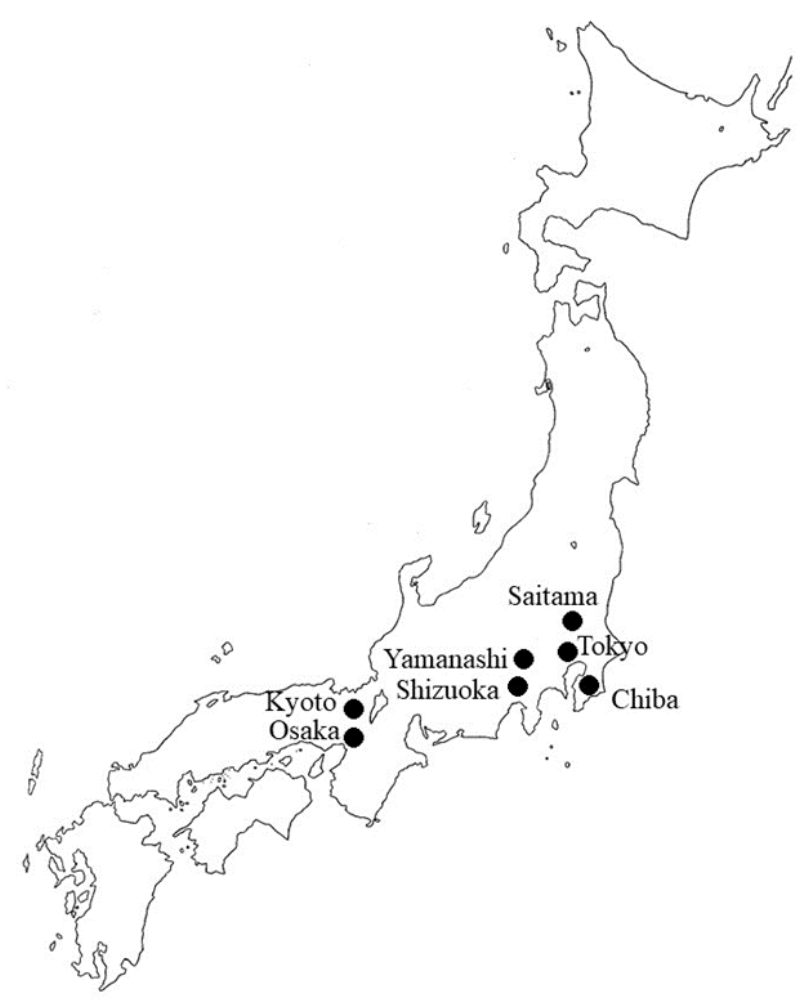

Figure $\mathbf{2}$ Map of Japan, with locations mentioned in the text.

US\$667 had been kept for seven or eight years (Tokyo Asabi Shimbun 1903). In addition, during Japan's modern monarchical period, it was very difficult for fanciers to breed frogs from eggs or tadpoles. Therefore, keepers bought young and small frogs and nurtured them until they grew to a large size.

To summarize, frogs that were collected from Kyoto, kept for a long time, and attained a large size were traded at a very high price. In contrast, small and young frogs that were captured in eastern Japan and sold in the market as soon as they had been collected from the rivers were cheap pets.

\section{Rearing Methods of B. buergeri by Fanciers}

There were almost no pet shops that specialized in reptiles and amphibians during the modern monarchical period. B. buergeri were sold in pet shops that also offered singing Orthoptera, birds, and goldfish, and sometimes they were even sold in candy stores (Yomiuri Shimbun 1892; Yorozu Chôhô 1900). In contemporary Japan, frog keepers usually feed the frogs with cheap crickets and mealworms that are bred as food for tropical fish, reptiles, amphibians, and birds. During the modern monarchical period, fanciers collected wild spiders and earwigs to feed their frogs, as insects for frogs were not commercially bred in those days. According to fanciers' rearing manuals, they gave their frogs 5-10 small insects per day (Hoshina 2018c).

One of the difficulties in keeping temperate frogs is overwintering. As winter approached, the fanciers prepared clay bottles and put fallen leaves, stones, and a small amount of water into them. Then, they put the frogs into the bottles and buried them in the ground under the floor (Tokyo Asabi Shimbun 1937b; Yomiuri Shimbun 1903c). In addition, during the 1920s, some keepers reared frogs in greenhouses during the winter and succeeded in having them sing throughout the year (Tokyo Asahi Shimbun 1921b).

Rich fanciers were very particular about rearing containers. They prepared containers made from black stones or put charcoal into them because they preferred black-ish to white-ish frogs (Tokyo Asabi Shimbun 1937c; Yomiuri Shimbun 1927b). Of course, fanciers knew well that frogs could change their dorsal colors, to a certain extent, to blend in with the background. In 1878, specialized frog rearing containers were sold out in Osaka (Figure 2). Some eager keepers reluctantly went to Tokyo just to get containers (Yomiuri Shimbun 1878). Fanciers were affectionate towards their frogs. Some fanciers mourned the loss of their pet frogs and held funerals for them (Tokyo Asabi Sbimbun 1917).

\section{A Limited Market for $\mathrm{B}$. buergeri}

In the modern monarchical period, newspapers often reported on a shortage of B. buergeri for sale (Tokyo Asabi Shimbun 1902; Yomiuri Shimbun 1884). The reason was that the number of $B$. buergeri circulating in the market was too small. For example, in 1887, the number of B. buergeri shipped from Yamanashi (Figure 2) to Tokyo's market was only three hundred (Yomiuri Shimbun 1887). Breeding B. buergeri was a hobby for rich people because the price was high, and the rearing of frogs took a great deal of time and money. Therefore, the B. buergeri market was relatively small in comparison to the market in pet animals and insects as a whole, even though the unit price of $B$. buergeri was high. In this respect, the $B$. buergeri trade contrasts with the trade in singing Orthoptera, which were pet insects for common people. For example, in 1930, one company breeding singing Orthoptera shipped over a hundred thousand insects to Tokyo's market (Hoshina 2017a). 
It was fortunate for the conservation of the wild population of $B$. buergeri that the market in these frogs was limited. In the modern monarchical period, a large number of fireflies were overhunted by professional services and delivered to buyers such as festival sponsors, department stores, and railway companies (Hoshina 2018a, 2018b). For example, in 1922, one company collected ten million wild fireflies and shipped them to Tokyo's market (Hoshina 2018b). At that time, fireflies were very cheap; therefore, one department store could stock a few million fireflies for free gifts to customers (Hoshina 2018b). Naturally, in the modern monarchical period, the population of Japanese fireflies was rapidly reduced by overhunting (Hoshina 2018b). In contrast, $B$. buergeri could escape overhunting because a relatively small number of them were collected from rivers and sold in the market. For this reason, $B$. buergeri is still a common species in Japanese mountain streams.

Moreover, the fact that the unit price of B. buergeri was high was also fortunate for the conservation of their regional genetic variation. In the modern monarchical period, sponsors often bought hundreds of thousands of fireflies for a festival. They would be brought them from the country to the city and released there for mass appreciation. It is possible that the artificial transportation of many fireflies from a distant area caused problems of genetic disturbance (Hoshina 2018b). However, it would have been challenging to prepare over 10,000 B. buergeri for festivals in the city, even if the sponsors were large department stores and railway companies, because $B$. buergeri were expensive. Consequently, it is believed that the genetic disturbance of B. buergeri did not arise in the modern monarchical period. At present, geographical differentiation in B. buergeri is confirmed by morphological and molecular biological studies (Matsui and Maeda 2018; Ueda et al. 1998), and generic disturbance of this frog has not been reported. Moreover, the National Institute for Environmental Studies recorded Japanese native thirteen species of frogs introduced to other area where they did not originally inhabit in Japan, but $B$. buergeri is not listed among them (Sarashina and Yoshida 2015).

\section{B. buergeri Presented to the Emperor}

During the modern monarchical period, royal families were sometimes presented with river frogs from ordinary people. For example, in 1885 one merchant offered an expensive frog to the Ministry of the Imperial Household (Tokyo Yokohama Mainichi Shinbun 1885).

Emperor Taishô (1879-1926; reigned from 19121926) loved river frogs. He visited Mie Prefecture in 1900 when he was crown prince and found many frogs in Isuzu River. He was delighted and ordered his retainers to catch two frogs (Tokyo Asabi Shimbun 1900). Crown prince Taishô was worried that frogs presented to him by a loyal subject would not sing at all in a pond of the Imperial Palace. However, they began singing in 1909 and he was satisfied with their beautiful songs (Yomiuri Sbimbun 1909).

Emperor Shôwa (1901-1989; reigned from 19261989), who succeeded Taishô, was a renowned biologist and interested in various life forms. In 1913, when Emperor Shôwa was crown prince, he went on an excursion to Tama River with 140 schoolmates and enjoyed listening to the songs of river frogs. Furthermore, he was presented with about 100 frogs from local elementary school students (Tokyo Asahi Shimbun 1913). He donated them to Emperor Taishô after going back to the Imperial Palace (Imperial Household Agency 2015).

In 1927, people in Mita village around Tokyo collected several thousand river frogs, selected 110 top class individuals, and presented them to the Ministry of the Imperial Household. These frogs were released at a pond at the Imperial Palace (Yomiuri Shimbun 1927a).

\section{B. buergeri Songs Broadcast Live by a Radio Station}

Japanese radio broadcasting began on March 22, 1925 (Takeyama 2002). In the 1930s, radio stations often broadcast songs of wild river frogs recorded live on the spot (Miyako Sbinbun 1936, 1937; Tokyo Asabi Shimbun 1937a, 1938, 1939; Yomiuri Shimbun 1939). If it happened to rain during a recording, the stations broadcast singing by human singers as opposed to frogs.

Change in Japanese People's Favorite Pets Before and After World War II

According to research on New York State pet shops in 1998-1999, the average price of eight native frog species was US $\$ 5$ and the most expensive frog, Scaphiopus bolbrookii, cost US $\$ 20$ (Horn 2003). In contrast, in a certain Japanese pet shop that currently specializes in amphibians, five native frog species, including B. buergeri, are sold at an average price of US\$21. The most expensive species, Bufo gargarizans 
miyakonis, costs US $\$ 48$, and B. buergeri costs US $\$ 11$. In this Japanese pet shop, most frog species are foreign and several are sold for US $\$ 300$ at most. Considering all of the aforementioned points, it could be concluded that B. buergeri, which cost more than US $\$ 1,000$ during the modern monarchical period, were at a premium, although they were common native species.

In the Edo Period (1603-1868), living B. buergeri were already sold as pets in what were then the three biggest cities, Edo (present Tokyo), Osaka, and Kyoto (Kanô 2011). Wealthy people in the modern monarchical period succeeded in breeding B. buergeri. Moreover, investment in railway infrastructure after 1868 enabled the transportation of $B$. buergeri from distant areas, and rearing techniques for the frogs were also improved. Furthermore, the general public began to enjoy $B$. buergeri songs through radio broadcasting, although they could not breed the frogs themselves. A culture of familiarity with B. buergeri was certainly developed in the modern monarchical period. However, Japanese people's favorite pets were clearly different during the modern monarchical period and after World War II. Japanese fanciers formerly reared singing Orthoptera, fireflies, and river frogs out of love (Hoshina 2017a, 2018b, 2018c), therefore they did not mind if their pets had a somber appearance. On the contrary, in contemporary Japan, many frog fanciers focus on pretty and colorful foreign species, such as the Argentine horned frog (Ceratophrys ornata), rather than native species. Moreover, contemporary insect fanciers do not breed singing Orthoptera of modest appearance, but attractive foreign stag and rhinoceros beetles (Hoshina 2019). Contemporary Japanese frog and insect fanciers select their pets for their appearance rather than emotional reasons.

\section{Declarations}

Permissions: This study was carried out under the University of Fukui Research Ethics Committee.

Sources of Funding: This work was supported by JSPS KAKENHI Grant Number JP18K00254.

Conflicts of Interest. None declared.

\section{References Cited}

Bureau of Environment, Tokyo Metropolitan

Government. 2013. Red Data Book Tokyo. Bureau of Environment, Tokyo Metropolitan Government, Tokyo. Available at: http://tokyo-rdb.jp/index.php. Accessed on April 8, 2020.
Horn, S. M. 2003. A Survey of New York State Pet Stores to Investigate Trade in Native Herpetofauna. Herpetological Review 34:23-27.

Hoshina, H. 2017a. Cultural Orthopterology in the Japanese Modern Monarchical Period. The Memoirs of the Research and Education Center for Regional Environment, University of Fukui 24:75-100.

Hoshina, H. 2017b. The Prices of Singing Orthoptera as Pets in the Japanese Modern Monarchical Period. Ethnoentomology 1:40-51.

Hoshina, H. 2018a. The Prices of Fireflies During the Japanese Modern Monarchical Period. Ethnoentomology 2:1-4.

Hoshina, H. 2018b. The History of Buying and Selling, and Releasing of Fire Flies (Coleoptera: Lampyridae) in the Japanese Modern Monarchical Period. Bulletin of Itami City Museum of Insects 6:5-21. DOI:10.34335/itakon.6.0_5.

Hoshina, H. 2018c. Cultural Amphibiology in the Japanese Modern Monarchical Period: A River Frog, Buergeria buergeri. The Memoirs of the Research and Education Center for Regional Environment, University of Fukui 25:127-136.

Hoshina, H. 2019. Cultural Coleopterology (Lucanidae) in Modern Japan. Sayabane, New Series 35:12-20.

Imperial Household Agency 2015. Biography of Emperor Shôwa, vol. 1. Tokyo-Shoseki, Tokyo.

Matsui, M., and N. Maeda. 2018. Encyclopedia of Japanese Frogs. Bun-ichi Co., Ltd, Tokyo.

Miyako Shinbun. 1907. A Market of Insects. Published on March 28, 1907.

Miyako Shinbun. 1936. Chorus of Buergeria buergeri from Jôshû and Sendai. Published on June 4, 1936.

Miyako Shinbun. 1937. Chorus of frogs. Published on July 3, 1937.

Morinaga, T. 2008. The Historical Dictionary of Commodity Prices. Tembo-sha, Tokyo.

Museum of Nature and Human Activities, Hyogo. 1997. Buergeria buergeri [web page]. Available at: https://www.hitohaku.jp/material/l-material/frog/ zukan/kajika.html. Accessed on April 8, 2020.

Sarashina, M., and T. Yoshida. 2015. Predation Impacts of Four Invasive Frogs in Hokkaido, Japan, Assessed by an Index of Relative Importance. Japanese Journal of Conservation Ecology 20:15-26. DOI:10.18960/hozen.20.1_15. 
Tokyo Asahi Shimbun. 1900. Crown Prince. Published on March 29, 1900.

Tokyo Asabi Shimbun. 1902. Notes of Pet Insects. Published on June 8, 1902.

Tokyo Asabi Shimbun. 1903. Various Pet Insects. Published on March 31, 1903.

Tokyo Asabi Shimbun. 1910. Notes of Pet Insects. Published on July 6, 1910.

Tokyo Asabi Shimbun. 1913. Crown Prince at Tama River. Published on March 8, 1913.

Tokyo Asabi Shimbun. 1917. Funerals of Small Birds and Buergeria buergeri. Published on September 24, 1917.

Tokyo Asabi Shimbun. 1921a. Buergeria buergeri. Published on August 11, 1921.

Tokyo Asabi Sbimbun. 1921b. Buergeria buergeri. Published on August 13, 1921.

Tokyo Asabi Shimbun. 1937a. Chorus of Buergeria buergeri from Sendai and Mt. Rokkô. Published on June 2, 1937.

Tokyo Asabi Shimbun. 1937b. Training of Buergeria buergeri. Published on June 15, 1937.

Tokyo Asabi Shimbun. 1937c. Training of Buergeria buergeri. Published on June 16, 1937.

Tokyo Asabi Shimbun. 1938. Chorus of Buergeria buergeri. Published on June 7, 1938.

Tokyo Asahi Shimbun. 1939. Radio Broadcasting from Cool Highlands. Published on July 18, 1939.

Takeyama, A. 2002. The History of Japanese Radios. Sekaishisôsha, Kyoto.

Tokyo Yokohama Mainichi Sbinbun. 1885. Buergeria buergeri in the Tama River. Published on June 19, 1885.

Ueda, H., Y. Hasegawa, and J. Marunouchi. 1998. Geographical Differentiation in a Japanese Stream-
Breeding Frog, Buergeria buergeri, Elucidated by Morphometric Analyses and Crossing Experiments. Zoological Science 15:615-622. DOI:10.2108/02890003(1998)15[615:GDIAJS]2.0.CO;2.

Usui, M. 1989. Frogs. Hôsei-daigaku-shuppankyoku, Tokyo.

Yomiuri Sbimbun. 1878. No titles. Published on July 19, 1878.

Yomiuri Shimbun. 1884. Buergeria buergeri. Published on June 14, 1884.

Yomiuri Shimbun. 1887. The Price of Buergeria buergeri. Published on July 28, 1887.

Yomiuri Sbimbun. 1892. The Price of Buergeria buergeri. Published on August 14, 1892.

Yomiuri Shimbun. 1902. A Market of Buergeria buergeri. Published on June 8, 1902.

Yomiuri Shimbun. 1903a. Merchants of Pet Insects. Published on March 20, 1903.

Yomiuri Shimbun. 1903b. Breeding Methods of Buergeria buergeri. Published on June 27, 1903.

Yomiuri Sbimbun. 1903c. Breeding Methods of Buergeria buergeri. Published on June 30, 1903.

Yomiuri Sbimbun. 1909. Buergeria buergeri at Imperial Palace. Published on June 28, 1909.

Yomiuri Shimbun. 1927a. Buergeria buergeri Presented to the Ministry of the Imperial Household. Published on July 8, 1927.

Yomiuri Shimbun. 1927b. Singing Buergeria buergeri. Published on July 12, 1927.

Yomiuri Sbimbun. 1939. Chorus of Buergeria buergeri from Yokote and Sendai. Published on June 6, 1939.

Yorozu Chôhô. 1900. Insect Shops. Published on June 11, 1900. 